NBER WORKING PAPER SERIES

\title{
BUBBLES IN METROPOLITAN \\ HOUSING MARKETS
}

Jesse M. Abraham

Patric H. Hendershot

Working Paper No. 4774

\section{NATIONAL BUREAU OF ECONOMIC RESEARCH 1050 Massachusetts Avenue \\ Cambridge, MA 02138 \\ June 1994}

This paper is part of NBER's research program in Public Economics. Any opinions expressed are those of the authors and not those of Freddie Mac or the National Bureau of Economic Research. 


\title{
BUBBLES IN METROPOLITAN \\ HOUSING MARKETS
}

\begin{abstract}
A commonsense and empirically supported approach to explaining metropolitan real house price changes is for the theory to describe an equilibrium price level to which the market is constantly adjusting. The determinants of real house price appreciation, then, can be divided into two groups, one that explains changes in the equilibrium price and the other that accounts for the adjustment dynamics or changing deviations from the equilibrium price.

The former group includes the growth in real income and real construction costs and changes in the real after-tax interest rate. The latter group consists of lagged real appreciation and the difference between the actual and equilibrium real house price levels. Either group of variables can explain a little over two-fifths of the variation in real house price movements in $\mathbf{3 0}$ cities over the $1977-92$ period; together, they explain three-fifths.
\end{abstract}

Jesse M. Abraham

Federal Home Loan Mortgage Corporation 8200 Jones Branch Drive McLean, VA 22102

and NBER
Patric H. Hendershott

Max M. Fisher College of Business The Ohio State University 1775 College Road

Columbus, OH 43210-1399 
Real house prices have swung sharply in metropolitan areas on the two U.S. coasts during the last decade (Abraham and Hendershott, 1993). In three Northeast clties for which we have data (Boston, Nassau-Suffolk and Newark), real prices rose by 92 percent during the 1983-88 period and through 1993 have since declined by 25 percent. In eleven west coast cities, real prices rose by over 50 percent between 1984 and 1990 and, so far, have declined by 15 percent. ${ }^{1}$ The rest of the country (excluding the mineral states that were devastated by the middle 1980s ofl price collapse) has not experienced such sharp fluctuations. For a sample of nine Upper Midwest and flve Southeast cities, real prices increased by only 13 percent in the 1983-92 decade, about reversing the earlier 1979-82 decline. Table 1 reports the growth of real house prices across 30 cities and in varlous reglons over the $1977-92$ period.

Real price movements in the stable Upper Midwest and Southeast are amenable to explanation with the basic Capozza-Helsley urban model (A\&A, 1993). Real construction cost inflation, real income growth, and changes in real after tax Interest rates alone explain about half of the varlation in real price inflhtion, and the explanation accounts for both the general real price decline in the early 1980 s and the recovery since then. The same variables help to explain real price movements in the rest of the country.

While A\&H's empirical results are correctly signed, of appropriate magnitude, statistically significant, and broadly consistent with the findings of other researchers, their model largely falls to explain the sharp, prolonged cycles in Northeast and West real house prices. That is, the results suffer not from large random standard errors, but rather from sustained, serlally correlated

1 Reports in the popular press of larger real price declines refer to larger houses than those in our sample. Higher price houses in California appear to have declined signiflcantly more than our "average" price houses (Case and Shiller, 1993). 
deviations, which are generally described as bubbles (Stiglitz, 1990).

Some earlier work suggests the existence of housing market bubbles. Case and Shiller (1989) report estimates where the lagged appreciation rate entered price regressions with a coefficient of 0.3 . The lagged appreciation rate is an obvious bubble-builder; once appreciation accelerates, the lagged variable magnifles the increase. Further, Shiller (1990) interprets survey results from four cities as indicating a strong extrapolation of recent local appreciation in the formation of expectations. He offers this as a possible reason "why speculative bubbles appear to be local phenomena, occurring in one city and not in another relatively nearby city" (p. 60). Finally, in our earlier paper, the lagged appreciation rate entered the regressions restricted to the more volatile coastal cities with a coefficient twice as large as in the stabler inland cities. suggesting that some cities may be more prone to bubbles than others.

But as bubbles grow larger and larger, they likely create an offsetting tendency to burst. Case and Shiller (1990) present weak evidence to this effect: the appreciation rate lagged more than one period enters negatively, although not with statistical significance. Incorporating a proxy for the tendency for bubbles to burst, as well as to build, is a major component of this paper. Our proxy is the deviation between the actual metropolitan house price level and a "fundamental" price level based upon our empirical estimation. ${ }^{2}$ The bubble buster proxy does indeed work and is especially useful in explaining the large cyclical swings in real house prices in the West. That is, the notion of adjustment to an equilibrium price seems to be a useful one.

Forecasts of future real house price appreclation thus depend on two

2 The use of this variable also addresses what some viewed as a shortcoming in our earlier paper, the absence of a role for variables reflecting the level of house prices (Wilcox, 1993). 
factors: forecasts of changes in fundamentals (real income and real after-tax Interest rates) and of initial gaps between actual and equilibrium price levels. Regarding the latter, it is widely percelved in early 1994 that houses in the coastal markets are "overpriced" and may continue to weaken, while houses in the oll and resource states are rebounding from "below equilibrium" prices. Our results provide no hints on future fundamentals, but we do have estimates of just how much more prices on the coasts may still need to fall in the absence of changes in fundamentals.

The body of the paper is partitioned into three parts. Section I presents the estimation model and the data. Section II reports the empirical estimates and Indicates both how well they explain real regional house price cycles and what disequilibria existed at the beginning of 1993. Section III contains some simulations to illustrate the real price dynamics implied by the estimates and the sensitivity of the dynamics to variation in the estimates. A conclusion closes.

\section{The Model and Data for the Explanatory Variables}

\section{The Model}

Capozza and Helsley (1989 and 1990) present models in which real land value is the sum of four components: the real value of agricultural land rent, the cost of developing the land for urban use, the value of "accessibility, " and the value of expected future real rent increases. Concern with the real value of houses adds the real cost of constructing houses to these components (this variable could also represent the cost-of-developing-land component). The conversion of a stream of rents into a value introduces the real-after-tax interest rate as a determinant of real house prices, and the value of accessibility should vary 
positively with real income in the metropolitan area.

Following this framework, Abraham and Hendershott (1993) express the growth In equilibrium real house prices (in a spectflc city) during period $t$, $p *_{t}$, as a Inear function of the growth In real construction costs, $c_{t}$, in real income per working age adult, $y_{t}$, and in employment, $e_{t}$, and the change in real aftertax interest rates, $\boldsymbol{r}_{\mathrm{t}}$.

$$
p^{*}=a_{0}+a_{1} c_{t}+a_{2} e_{t}+a_{3} y_{t}+a_{4} r_{t}
$$

With an "error term, " $\theta_{\mathrm{t}}$, reflecting adjustment dynamics (e.g., bubbles) as well as random error, we have:

$$
p_{t}=p^{*}+\theta_{t}
$$

Regarding the adjustment dynarics, we specify the error term as

$$
\theta_{t}=\lambda_{0}+\lambda_{1} p_{t-1}+\lambda_{2}\left(\log P_{t-2}-\log P_{t-1}\right)+\theta_{t}
$$

where $\log P *_{t-1}-\log P_{t-1}$ is the $\log$ difference between the equilibriun and actual real price levels (in city 1 ) at the beginning of period $t$ and $\Phi_{t}$ is a random error. (All growth rates are measured as $\log$ differences.) For convenience, the disequilibrium measure is calculated as the simple difference in two log-levels, rather than the percentage difference between nominal indices. Other things equal, the greater the real price change the previous period or the equilibriumactual price difference at the beginning of the perlod, the larger will be the actual price change during the perlod. For $\lambda_{1}$ positive, the first variable acts to perpetrate growth, generating a price bubble; the second variable, for $\lambda_{2}$ positive, captures the tendency of the bubble to eventually burst. Substituting equs (1) and (3) into equ (2), we have 


$$
p_{t}=\left(a_{0}+\lambda_{0}\right)+a_{1} c_{t}+a_{2} e_{t}+a_{3} y_{t}+a_{t} x_{t}+\lambda_{1} p_{t-1}+\lambda_{2}\left(\log P t_{t-1}-\log P_{t-1}\right)+\Phi_{t}
$$

The econometric difficulty is that equ $\left(2^{\prime}\right)$ cannot be estimated without knowing $P^{*}$, which 1 tself depends on the estimates from $\left(2^{\prime}\right)$. In effect, we need to use values of $P \star_{t-1}$ in the estimation of $\left(2^{\prime}\right)$ that are consistent with the $p{ }^{\prime}$ 's that we compute after the estimation.

We finesse this difficulty by first estimating equ (2') without the $\lambda_{2}$ term. We then calculate $p^{*}$ and cumulate $1 t$ over time to obtain a first-pass time series on $P *_{t-1}$ for each clty. To illustrate, if we assumed that house prices were in equilibrium in the inftial year $(t-0)$, we would compute $\log *^{*} t-1$ as

$$
\log P_{t-1}=\log P_{0}+\sum_{1-1}^{t-1} p^{*} t
$$

An Index for $P$ would be constructed simflarly by replacing $p *_{1}$ with $p_{1} \cdot{ }^{3}$

In the empirical estimation, we set $P_{0}=P *_{0}-1$ in 1983 and use the firstpass estimates of $p *_{1}$ to compute $P *_{t-1}$. We then add $\left(\log P *_{t-1}-\log P_{t-1}\right)$ to equ (2') for reestimation. If $\log P \star_{t-1}-\log P_{t-1}, p_{t-1}$ and the determinants of $p *$ are uncorrelated, the estimates of the $a^{\prime} s$ and thus of $p \star_{1}$ will be unchanged. If the estimated regression coefficients change, we then recompute $\log P \star_{t}$ from equ (4) and reestimate equ (2'). After a few iterations, the coefficient estimates stabllize so that the $\mathrm{p}^{*}$ and $\mathrm{P*}$ estimates are consistent (generally, three Iterations are required).

3 If equilibrium were assumed to exist in year $n$, we would compute values after $n$ as in equ (4) but with $P_{n}$ replacing $P_{0}$. For values before $n, \log P_{n}$ is reduced by $\Sigma-p^{*}-1$, where the "sum" goes backward from $n$.

4 We choose 1983 because the early 1980 s were a period of generally falling real prices in the West and especially the Midwest, while after 1983 real prices exploded in the West and especially the Northeast. 


\section{Empirtcal proxies}

Our source for metropolitan price data is a combined Fannie-Mae/Freddie-Mac repeat-sale data base (Stephens, et,al, 1993). For a general construction cost measure, we use the National Income and Product Accounts residential deflator, which is really the Census Bureau deflator for new houses excluding the value of the lot, not an index for both multifamily and single family construction. To obtain city-specific cost estimates, we multiply the general index by the appropriate R.S. Means Company city index adjustment factor. The R.S. Means cost survey is applicable for industrial and commercial construction projects.

The local CPIs net of shelter are from Data Resources/McGraw-Hill. Employment data and population aged 25-64 are from Regional Financial Associates (RFA). Income data are from the Bureau of Economic Analysis, Department of Commerce. Because the 1992 MSA income and population estimates are not yet available, we have used RFA forecasts to estimate these numbers. The general deflator is the CPIU-XI, which is the official national consumer price index beginning in 1982 and the official index purged of the mismeasurement caused by rapid increases in mortgage rates in the late 1970 s and early 1980 s (see the Economic Report of the President).

We specify the real after-tax interest rate as the nominal

after-tax rate less a weighted average of the expected national general inflation rate and the expected local house price inflation rate:

$$
R=(1-\tau) 1-[w p n+(1-w) p l] \text {, }
$$

where 1 is a nominal interest rate, is the relevant tax rate, pn is the expected national inflation rate, pl the expected local house price inflation rate, and $w$ is the weight given to the national rate. This expression can be rewritten as 


$$
R-[(1-\tau) 1-p n]+(1-w)(p n-p 1)
$$

We include both the bracketed first term (the RAT interest rate using the expected national inflation rate) and (pn-pl) as regressors. The weight applied to the national appreciation rate, 1-w, can then be computed as the coefficient on the inflation differential divided by that on RAT.

We use the one-year Treasury rate for the financing rate and the previous year's national CPI appreclation rate for expected general 1nflation and the previous year's local house price appreciation for the local expected appreciation. Poterba's time series on the marginal tax rate for households with real adjusted gross income of $\$ 30,000$ in 1990 is employed (the 1990 tax rate is assumed to hold in 1991 and 1992).

\section{Empirical Estimates}

Table 2 contains the basic model estimates. Colum 1 reproduces the estimates from our earlier study, and column 2 11sts comparable estimates for the new data set. The new set differs from the old in two major respects. First, the dependent variable is now computed from a jolnt Fannie-Freddie data set of repeat transactions. Second, we were able to fix up the real employment growth variable. As a result, we have added an intermediate year (1982) and a c1ty (Seattle) to the data base. W1th the further addition of 1992, the data base is expanded from 319 observations to 420 ( $30 \mathrm{clties}$ for 14 years).

As can be seen by comparing columns 1 and 2 , the data revision and extension do not alter the results significantly. Only the coefficient on the change-1n-local-price deviation changes by over 12 percent or more than half a standard deviation. All t-ratios rise, with that on the change-1n-local-price deviation increasing the most, -1.5 to -3.5 . 
Both employment growth and real income growth per adult work as expected. In the earlier paper, we noted that which variable is theoretically appropriate depends on the model assumptions. Here we have experimented some with different real Income growth measures. Column 3 gives the result with the variables replaced by a total real income growth. As can be seen, it performs slightly better than the two components used in the earlier paper.

The specification in column 3 is reproduced for comparison in column 1 of Table 3. Column 2 includes the new variable reflecting the percentage deviation of actual from estimated-equilibrium price levels. While the coefficient is statistically significant with the expected sign, the coefficient is a small 0.05 and raises the equation explanatory power by a trivial amount.

Next, we divide the sample roughly into halves: the 14 cities in the Northeast and West and the other 16 cities (Upper Midwest, Southeast and Texas). We have lumped "Texas" with the Midwest and Southeast, but this is a far from perfect aggregation. Dallas and Houston price behaviors differ from each other and from any other region (see Table 1). Prior to the most recent 1987-92 period, Dallas is much like the Upper Midwest, but in the most recent period its price decline is even more severe than in the West. Houston is like the Southeast, except in the middle 1980s, when Houston experienced sharp real price declines.

The empirical estimates in columns 3 and 4 suggest common responses of the "coastal" and "Inland" cities to real income growth and the user cost variables (changes in real after-tax interest rates and local price deviation), but substantially different responses to the disequilibrium variables (lagged appreciation rate and deviation of the actual from equilibrium price level) and to construction cost inflation. The common coefficients are similar to those in 
column 2: 0.7 on real income growth, -0.5 on the change in real after-tax interest rates and -0.15 on the change in relative inflation. The coefficient on construction cost inflation is only 0.16 for the Northeast-West versus 0.57 for the rest of the country. Moreover, evidence of price bubbles is much stronger for the Northeast-West (coefficients of 0.5 on lagged appreciation and 0.10 on the price disequilibrium variable) than for the rest of the country $(0.2$ for lagged appreciation and effectively zero for the disequilibrium variable). Column 5 combines the two subsamples, but allows for different constants and differential impacts of construction cost inflation, lagged appreciation, and disequilibrium (constrained to zero for the 16 city group). The coefficient estimates are as expected, with a slightly improved R-squared. Table 4 uses these estimates to determine the ability of the model to explain the substantially different movements in real reglonal house prices since 1983 . The decade is divided into the boom years of 1983-88 (1983-90 for the West) and the subsequent bust. We report, for four reglons, the actual cumulative log change, the fitted, and the dynamically simulated. In the latter, we substitute, beginning in 1984, the predicted real price change for the actual lagged price change and in calculation of the lagged price level in the disequilibrium variable.

Comparing the actual and simulated changes, we explain roughly threequarters of real price swings in the Southeast, Upper Midwest and the West, about half the changes in the Northeast, and only about a quarter in Texas. The explanations for the West, Northeast and even Texas are substantial improvements on our earlier paper (contrast, AdH, 1993, table 9). Of course, the Texas results are still far from satisfactory.

Next, we decompose the cumulative actual price appreciation since 1983 (the 
equilibrium year) into an increase in the equilibrium price and a residual, which is simultaneously determined with the equilibrium process. The qualitative results regarding current disequilibria, shown in Table 5, are consistent with expectations; the coasts were overpriced in 1992, Texas was underpriced, and the great in-between was fairly priced. But $1 t^{\prime}$ s worth looking more closely at each area's numerical results.

Real prices in the Northeast rose 92 percent from 1983 through 1988, before dropping 25 percent through 1992. Over the same 1983-88 period, the equilibrium rate grew at a historically rapid 3 plus percent a year, but that still left a yawning 50 percent gap in 1988 between actual and equilibrium prices. Actual levels have fallen more than equilibrium price since then, but the equation suggests that a 30 percent gap remained at the end of 1992 (probably 25 percent at the end of 1993). Unfortunately, because we were able to explain only 60 percent of the mid1980s surge, we may well have under-forecasted the equilibrium price rise, and thus the actual-equilibrium price gap could be less than 25 percent.

In both the Southeast and the Midwest, real prices rose by much smaller amounts between 1983 and 1992, and actual prices remained within a few percent of the equilibrium level in the 1980s. Texas is the inverse of the Northeast: property values collapsed and for reasons not well captured in the model. Thus, we have a huge 35 percent measure of underpricing and very little confidence in it.

The Western regions had smaller cumulative increases than the Northeast, and the fundamentals were stronger overall. Thus the disequilibrium gaps are a smaller 15 and 20 percent. While real prices fell significantly in 1993, how much was a closing of the 1992 gap and how much was a further deterioration in 
California's fundamentals is unclear.

III. House Price Dynamics

of perhaps greater interest than the numerical results for specific regions are the implications of the estimates for reglonal house price dynamics. The error term $\theta$, as specifled in equation (3), presents a dynamic tension for the effect of lagged price change on current price inflation: lagged change enters with a positive coefficlent as a growth rate and with a negative coefficient through the lagged price level.

simulations of price booms and busts using the estimated values of $\lambda_{1}$ and $\lambda_{2}$ are presented in Figure 1. Four different 'boom' scenarios are overlaid on top of an equilibrium growth rate of 1 percent. ${ }^{5}$ After being at equilibrium. actual annual real appreciation is assumed to run for four years annually at: 14 percent (the Northeast), B percent (California), 4 percent (Midwest), and 1 percent (trend). A dynamic solution starts in the fifth year (year 1 in the chart), with the inflation rate equal to the sum of the equilibrium rate ( 1 percent) and the error term. The formula for the exror term is:

$$
0.5 p_{t-1}+0.1\left[\sum_{1=1}^{t-1} p_{1}-\sum_{1=1}^{t-1} p_{1}\right]
$$

which is equation (2') with values for $\lambda_{1}$ and $\lambda_{2}$ taken from colurn 5 of Table 3 for the coastal cities. There are no stochastic errors in these simulations. ${ }^{6}$

In the "Northeast" simulation, the disequilibrium term quickly drives

5 Averaging the components of the equilibrium growth rate formula: construction costs, real income, real after tax inflation rate, relative inflation, and the constant, across time and the 14 coastal cities ylelds an annual growth rate of 1.2 percent, rounded to 1 percent.

- These house price simulations are similar to the wage disinflation simulation developed in Abraham (1987). 
appreciation negative because the price level is very high relative to the equilibrium level (in year 5 , the $\log$ difference is 4 - 56 - 52 percent). Real changes stay negative through the twelfth year; if nominal general inflation is 3 percent, nominal house price inflation will turn positive in year 8 . This assumes that the equilibrium level continues growing at one percent annually. Should the economic fundamentals temporarily worsen, as they did in Boston, a sharper decline and stronger bounce back could be observed.

As 1llustrated by the "California" and "Midwest" simulations, more modest disequilibria impose less wrenching adjustments. In fact, real house price appreciation in the Midwest is negative for only two years and then by trivial amounts. Within 20 years, all four simulations have stabilized at an identical 'equilibrium' price level that is growing steadily at 1 percent per year. (In practice, changes in the equilibrium growth rate and stochastic shocks will alter the timing along the disequilibrium path.) These empirically estimated coefficients imply it can take a long time .. up to a decade - for price inflation in areas with long-term strength to recover from the bursting of a bubble. ${ }^{7}$

The adjustment coefficients are, of course, estimated with error. Figure 2 illustrates the sensitivity of the Northeast adjustment path to combinations of increases and decreases of two standard errors in the coefficients, 0.1 for $\lambda_{1}$ and 0.05 for $\lambda_{2}$. With a higher coefficient on the disequilibrium price variable, the decline is steeper and more abrupt because the overpricing premium is eliminated more rapidly. With high coefficients on both the lagged appreciation rate and the disequilibrium price, the price actually overshoots and

7 Similar to the results here, Blanchard and Katz (1992) find a peak house price response to an employment shock in years 4-5, with the total effect disappearing only after 12 years. 
eventually has to rise at greater than a one percent rate. With a high coefficient on the lagged appreciation rate but a low coefficient on the disequilibrium variable, the decline is relatively slow (appreciation is not negative until the third year), but longer lasting.

The adjustment path is also sensitive to the underlying fundamentals. The Figure 3 simulation examines the sensitivity of the California scenario to equilibrlum growth rates of 0,1 , and 2 percent. Clearly zero growth is the most draconian, requiring that all of the 20 percent overpricing be unwound. Real prices fall for a decade. In contrast, with two percent equilibrium growth, roughly what the west coast experienced in the 1980 s, real prices decline for only two years. This implies that it is not enough to know (believe) that houses are overvalued by, say, 20 percent to forecast where values will be a year from now. Even in such a case, the extent to which the equilibrium path is rising or falling makes a fundamental contribution to real appreclation (depreciation).

IV. Conclusion

The last few years have seen the widely expanded avallability of high quality, constant-quality house price Indices for metropolitan areas. As price trends are a very localized phenomenon, a myriad of exciting research opportunitles are opening up. In this paper, we bulld upon an earlier attempt (A\&H, 1993) to understand cross sectional annual variation in real house price movements In 30 citles over the 1977-92 period.

A commonsense and empirically supported approach is for the theory to describe an equilibrium price level to which the market is constantly adjusting. The determinants of real house price appreciation, then, can be divided into two groups, one that explains changes in the equilibrium price and the other that 
accounts for the adjustment dynamics or changing deviations from the equilibrium price. The former group includes the growth in real income and real construction costs and changes in the real after-tax interest rate. The latter group consists of lagged real appreciation and the difference between the actual and equilibrium real house price levels. Either group of variables can explain a little over two-fifths of the variation in our sample; together, they explain three-fifths. Substantial real house price booms occurred on the two coasts during the middle and late 1980 s and real prices have since been declining. Our model can explain roughly three-quarters of real price swings in the West (as well as the smaller changes in the Southeast and Midwest), and about half the changes in the Northeast. However, little of the general decline in real prices in Dallas and Houston is explained.

When this approach is applied across the country, we find as of end 1992 a huge 30 percent 'above market' premium in prices in the Northeast, a 15-20 percent premium in west coast prices, and probably significant underpricing in Texas. Given our inability to explain part of the earlier rise in the Northeast, that premium is probably too large. While some of the coastal premia undoubtedly eroded in 1993, a further deterioration of fundamentals in California may also have occurred. Thus a best guess is about a 15 percent premium on both coasts in early 1994. The majority of the country, as represented by our Midwestern and Southeastern cities, is near equilibrium.

How rapidly the presumed 15 percent premia will be eliminated is uncertain. The basic coefficient estimates suggest the years of most intense declines occur 3-6 years after the boom ends, with a possibly very long period of adjustment .. up to a dozen years of falling real prices. Favorable economic trends can significantly blunt the magnitude of the house price disinflation required 
following a boom.

Many mysteries remain. The lagged appreciation term that represents speculative pressures in the market performs admirably in soaking-up volatility, but we still lack a compelling explanation for why it is needed, 1.e., we don't really know what starts the speculative bubbles. Even the detective work in Case and Shiller (1993) does more to track the observed boom in real prices during the 1980 s than to explain why it occurred in the first place. In terms of the Capozza-Helsley model, we have Identifled a role for real income growth, but we have been unable to identify changes in the expected growth path. Another possibility is differing supply restrictions - - or lack of restrictions in places such as in Texas - that cause real income growth spurts to have greater impacts In some areas than in others. ${ }^{B}$ It is these areas that we recommend future researchers explore.

- We spent considerable time trying to fit cross-sectional measures of land restrictions from Godschalk and Hartzell (1992) into our equations and were unsuccessful in finding more than a token effect. 


\section{REFERENCES}

Abraham, Jesse M. and Patrlc H. Hendershott, "Patterns and Determinants of Metropolitan House Prices, 1977-91," In Real Estate and the Credit Crunch, Browne and Rosengren (eds.), Proceedings of the 25th Annual Boston Fed Conference, 1993, 18-42.

Abraham, Jesse M., "Income Redistribution During a Disinflation," Journal of Macroeconomics, (9:2), Spring 1987, 203-221.

Blanchard, Oltvier Jean, and Lawrence F. Katz, "Reglonal Evolutions," Brookings Papers on Economic Activity, 1992:1, 1-76.

D. Capozza and R. Helsley, "The Fundamentals of Land Prices and Urban Growth," Journal of Urban Economics, 26, 1989, 295-306.

, "The Stochastic City," Journal of Urban Economics, 28, September $1990,187-203$.

Case, Karl E., and Robert J. Shiller, "A Decade of Boom and Bust in Single Family Home Prices: Boston and Los Angeles, 1983-1993, mimeo, November 14, 1993.

, "The Efficiency of the Market for Single-Family Homes," American Economic Revtew, March 1989, 125-137.

_, "Forecasting Prices and Excess Returns in the Housing Market, " AREUEA Journal, Fall 1990, 253-273. 
Godschalk, David R., and David J. Hartzell, Urban Development Land Supply: Constraints and Opportundties in Large MSAs, presented to a Prudential Realty. North Carolina Seminar, May 1992.

Poterba, James M., "House Price Dynamics: The Role of Tax Policy and Demography," Brookings Papers on Economic Activity, 1991:2, 143-83.

Shiller, Robert J., "Speculative Prices and Popular Models, " Journal of Economic Perspectives, Spring 1990, 55-65.

Stephens, William, Ying Li, Jesse M. Abraham, Vassilis Lekkas, Charles Calhoun and Tom Kimner, "Agency Repeat Transactions Index," mimeo, 1993.

Stiglitz, Joseph, "Symposium on Bubbles," Journal of Economic Perspectives, Spring 1990, 13-18.

Wilcox, James A., "Discussion of Abraham and Hendershott 'Patterns and Determinants of Metropolitan House Prices, 1977-91," in Real Estate and the Credit Crunch, Browne and Rosengren (eds.), Proceedings of the 25th Annual Boston Federal Reserve Conference, 1993, 51-56. 
Tats $1^{\circ}$.

MEAL MOUSE MALE ANTEECA TOM

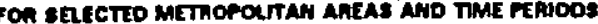

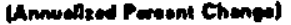

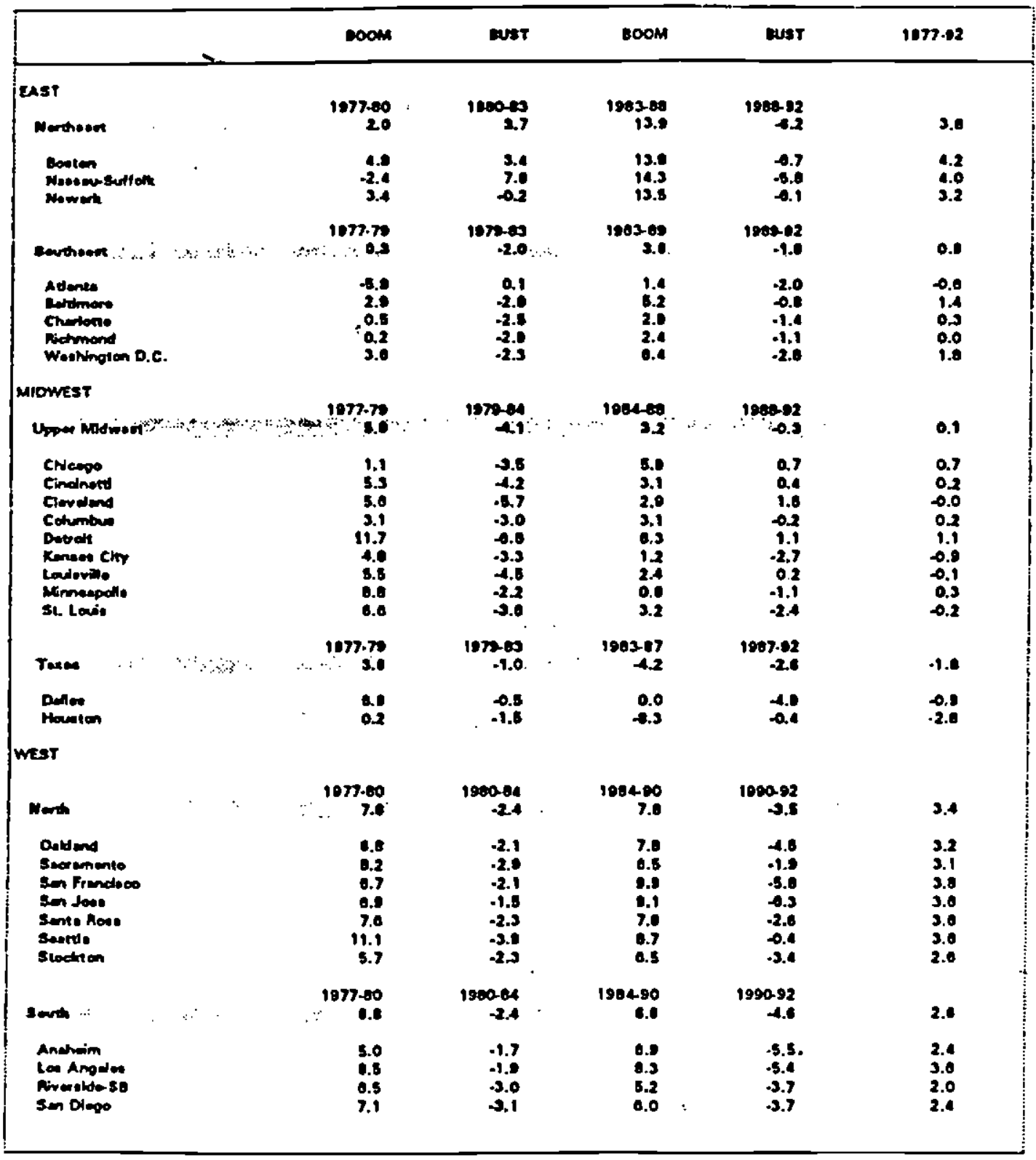


Table 2: Explanation of Real Price Appreciation (30 cities, 1977-92)

\begin{tabular}{|c|c|c|c|}
\hline & $\begin{array}{c}(1) \\
\text { A\&H } \\
(4.5)\end{array}$ & $\begin{array}{l}(2) \\
\text { Updated } \\
\text { Data }\end{array}$ & $\begin{array}{l}(3) \\
\text { Combined } \\
\text { Growth } \\
\text { Terms }\end{array}$ \\
\hline Cons tant & $\begin{array}{l}-.006 \\
(-2.1)\end{array}$ & $\begin{array}{l}-.006 \\
(-2.1)\end{array}$ & $\begin{array}{l}-.017 \\
(-5.8)\end{array}$ \\
\hline $\begin{array}{l}\text { Real Construction } \\
\text { Cost Inflation }\end{array}$ & $\begin{array}{l}.457 \\
(4.2)\end{array}$ & $\begin{array}{l}.464 \\
(4.7)\end{array}$ & $\begin{array}{l}.365 \\
(3.8)\end{array}$ \\
\hline $\begin{array}{l}\text { Employment } \\
\text { Growth }\end{array}$ & $\begin{array}{l}313 \\
(3.2)\end{array}$ & $\begin{array}{l}345 \\
(3.5)\end{array}$ & $\begin{array}{c}.774 \\
(10.1)\end{array}$ \\
\hline Real Income & .565 & .500 & \\
\hline Growth per Adult & $(4.4)$ & $(4.7)$ & . \\
\hline $\begin{array}{l}\text { Change in Real } \\
\text { After-Tax } \\
\text { Interest Rate }\end{array}$ & $\begin{array}{l}-.593 \\
(-4.4)\end{array}$ & $\begin{array}{l}-.551 \\
(-4.5)\end{array}$ & $\begin{array}{l}-.469 \\
(-4.1)\end{array}$ \\
\hline $\begin{array}{l}\text { Change in Local } \\
\text { Price Deviation }\end{array}$ & $\begin{array}{l}-.072 \\
(-1.5)\end{array}$ & $\begin{array}{l}-.143 \\
(-3.5)\end{array}$ & $\begin{array}{l}-.151 \\
(-3.8)\end{array}$ \\
\hline $\begin{array}{l}\text { Lagged Real } \\
\text { Appreciation }\end{array}$ & $\begin{array}{l}.402 \\
(8.7)\end{array}$ & $\begin{array}{l}362 \\
(9.9)\end{array}$ & $\begin{array}{c}.382 \\
(11.3)\end{array}$ \\
\hline R2 & .54 & .53 & .55 \\
\hline Observations & 319 & 420 & 420 \\
\hline
\end{tabular}


Table 3: Real Price Appreciation Allowing Different Responses for Coastal and Texas Cities

\begin{tabular}{|c|c|c|c|c|c|}
\hline & $\begin{array}{l}\text { (1) } \\
\text { all }\end{array}$ & $\begin{array}{l}(2) \\
\text { a11 }\end{array}$ & $\begin{array}{c}\text { (3) } \\
\text { inland } \\
16 \text { cities }\end{array}$ & $\begin{array}{c}\text { (4) } \\
\text { coastal } \\
14 \text { cities }\end{array}$ & $\begin{array}{l}(5) \\
\text { a11 }\end{array}$ \\
\hline Constant & -.017 & $\begin{array}{l}-.015 \\
(-4.8)\end{array}$ & $\begin{array}{l}-.018 \\
(-5.2)\end{array}$ & $\begin{array}{l}-.006 \\
(-0.8)\end{array}$ & $\begin{array}{l}-.018 \\
(-5.9)\end{array}$ \\
\hline Constant* & & & & & $\begin{array}{l}.012 \\
(2.8)\end{array}$ \\
\hline $\begin{array}{l}\text { Constr. Cost } \\
\text { Apreciation }\end{array}$ & .365 & $\begin{array}{l}352 \\
(3.7)\end{array}$ & $\begin{array}{l}.573 \\
(5.2)\end{array}$ & $\begin{array}{l}.163 \\
(1.0)\end{array}$ & $\begin{array}{l}.575 \\
(5.3)\end{array}$ \\
\hline $\begin{array}{l}\text { Constr. Cost* } \\
\text { Appreciation }\end{array}$ & & & & & $\begin{array}{l}-.420 \\
(-2.3)\end{array}$ \\
\hline $\begin{array}{l}\text { Real Income } \\
\text { Growth }\end{array}$ & .774 & $\begin{array}{l}.730 \\
(9.3)\end{array}$ & $\begin{array}{l}.687 \\
(7.7)\end{array}$ & $\begin{array}{l}.683 \\
(4.7)\end{array}$ & $\begin{array}{l}.684 \\
(9.2)\end{array}$ \\
\hline$\triangle R A T I R$ & -.469 & $\begin{array}{l}-.473 \\
(-4.2)\end{array}$ & $\begin{array}{l}-.481 \\
(-3.8)\end{array}$ & $\begin{array}{l}-.528 \\
(-2.5)\end{array}$ & $\begin{array}{l}-.495 \\
(-4.6)\end{array}$ \\
\hline $\begin{array}{l}\text { Change in } \\
\text { Relative Inflation }\end{array}$ &. .157 & $\begin{array}{l}-.114 \\
(-2.7)\end{array}$ & $\begin{array}{l}-.176 \\
(-3.4)\end{array}$ & $\begin{array}{r}-.159 \\
(2.5)\end{array}$ & $\begin{array}{l}-.173 \\
(-4.4)\end{array}$ \\
\hline $\begin{array}{l}\text { Lagged } \\
\text { Inflation }\end{array}$ & .382 & $\begin{array}{c}.423 \\
(11.6)\end{array}$ & $\begin{array}{l}.193 \\
(3.6)\end{array}$ & $\begin{array}{c}.515 \\
(10.0)\end{array}$ & $\begin{array}{l}197 \\
(4.2)\end{array}$ \\
\hline $\begin{array}{l}\text { Lagged } \\
\text { Inflation* }\end{array}$ & & & & & $\begin{array}{l}-311 \\
(5.0)\end{array}$ \\
\hline $\begin{array}{l}\text { Deviation from } \\
\text { Equilibrium }\end{array}$ & & $\begin{array}{l}.050 \\
(2.7)\end{array}$ & $\begin{array}{l}-.005 \\
(-0.1)\end{array}$ & $\begin{array}{l}.102 \\
(3.8)\end{array}$ & \\
\hline $\begin{array}{l}\text { Deviation from } \\
\text { Equilibrium* }\end{array}$ & & & & & $\begin{array}{l}.095 \\
(3.9)\end{array}$ \\
\hline $\mathrm{R}^{2}$ & .55 & .56 & .55 & .59 & .60 \\
\hline Observations & 420 & 420 & 224 & 196 & 420 \\
\hline
\end{tabular}

*Variables multiplied by a dummy varlable that is 1 for the 14 coastal cities. 
Table 4

Cumulative Log Changes, 1983-92:

Actual, Fitted, and Dynamically Simulated

1983-1988

$\underline{1988-1992}$

Northeest

$\begin{array}{lll}\text { Actual } & 64.9 & -25.6 \\ \text { Fitted } & 39.4 & -30.6 \\ \text { Simulated } & 30.6 & -13.0\end{array}$

Southeast and Upper Midwest

$\begin{array}{lll}\text { Actual } & 15.2 & -2.2 \\ \text { Fitted } & 11.6 & -3.2 \\ \text { Simulated } & 12.3 & -6.0\end{array}$

Texas

$\begin{array}{lrr}\text { Actual } & -26.0 & -4.7 \\ \text { Fitted } & -8.8 & -3.7 \\ \text { Simulated } & -6.4 & -1.4\end{array}$

West
Actual
40.2
38.6
29.7
$-8.0$
$-7.5$
$-5.3$

*In the West, the time periods are 1983-90 and 1990-92. 
Table 5

Price Level Disequilibrium as of 1992

(Percent)

$\begin{array}{ccl}\text { Cumulative } & \text { Cumulative } & \text { Disequilibrium } \\ \text { Actual Growth } & \text { Equil. Growth } & \text { as of end1992 } \\ \text { since 1983 } & \text { since 1983 } & \end{array}$

East

$\begin{array}{llll}\text { Northeast } & 41 & 11 & 30 \\ \text { Southeast } & 16 & 15 & 1\end{array}$

M1dwest

Upper Midwest 10

Texas $\quad-32$

$3-35$

West

40

20

20

South

31

16

15 


\section{Figure 1}

Simulation of House Price Paths

with Alternative Initial Conditions

(Percent)

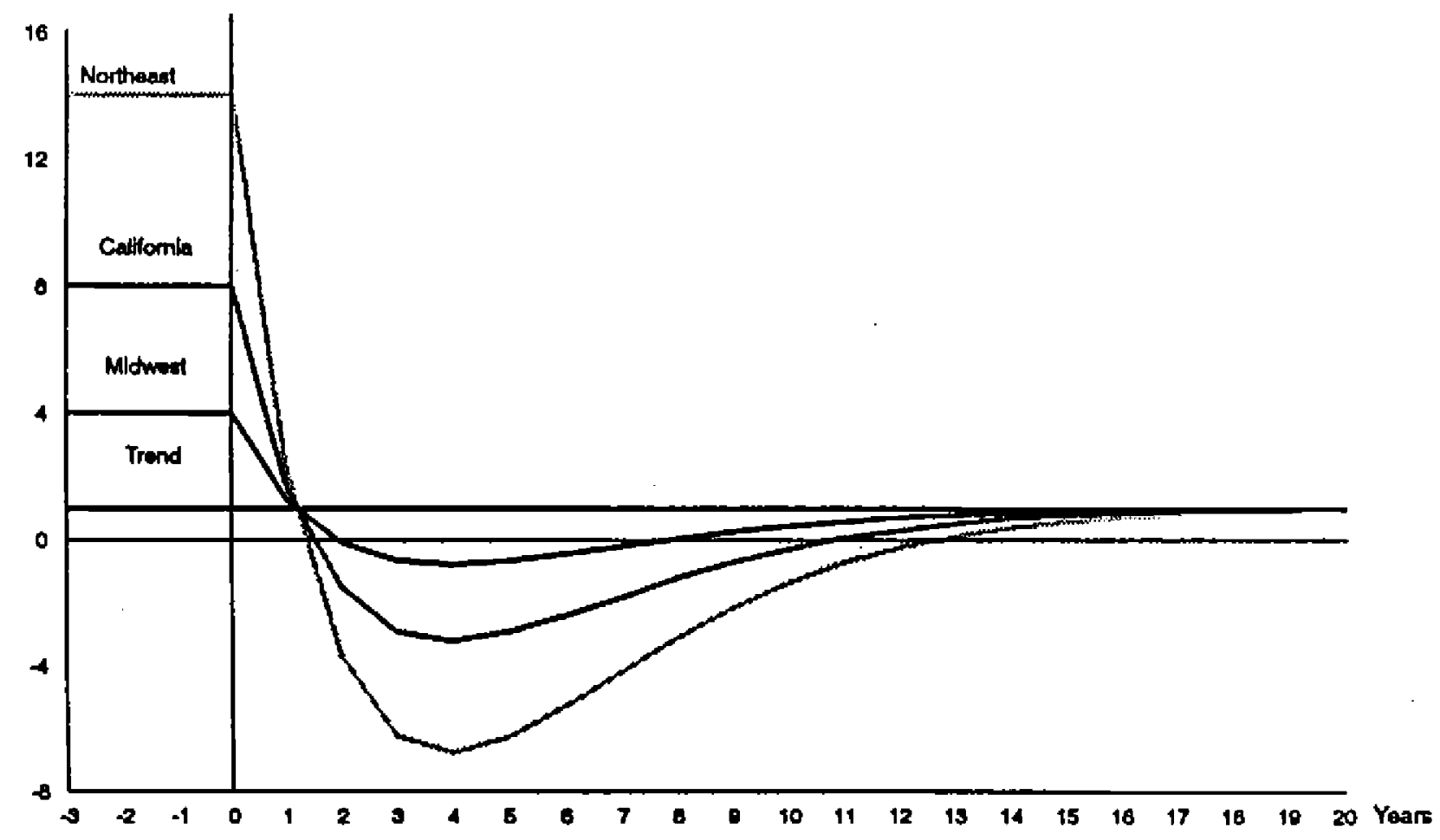


Figure 2

Simulation of House Price Paths

Showing Range with \pm Two Standard Errors on Coefficients (Percent)

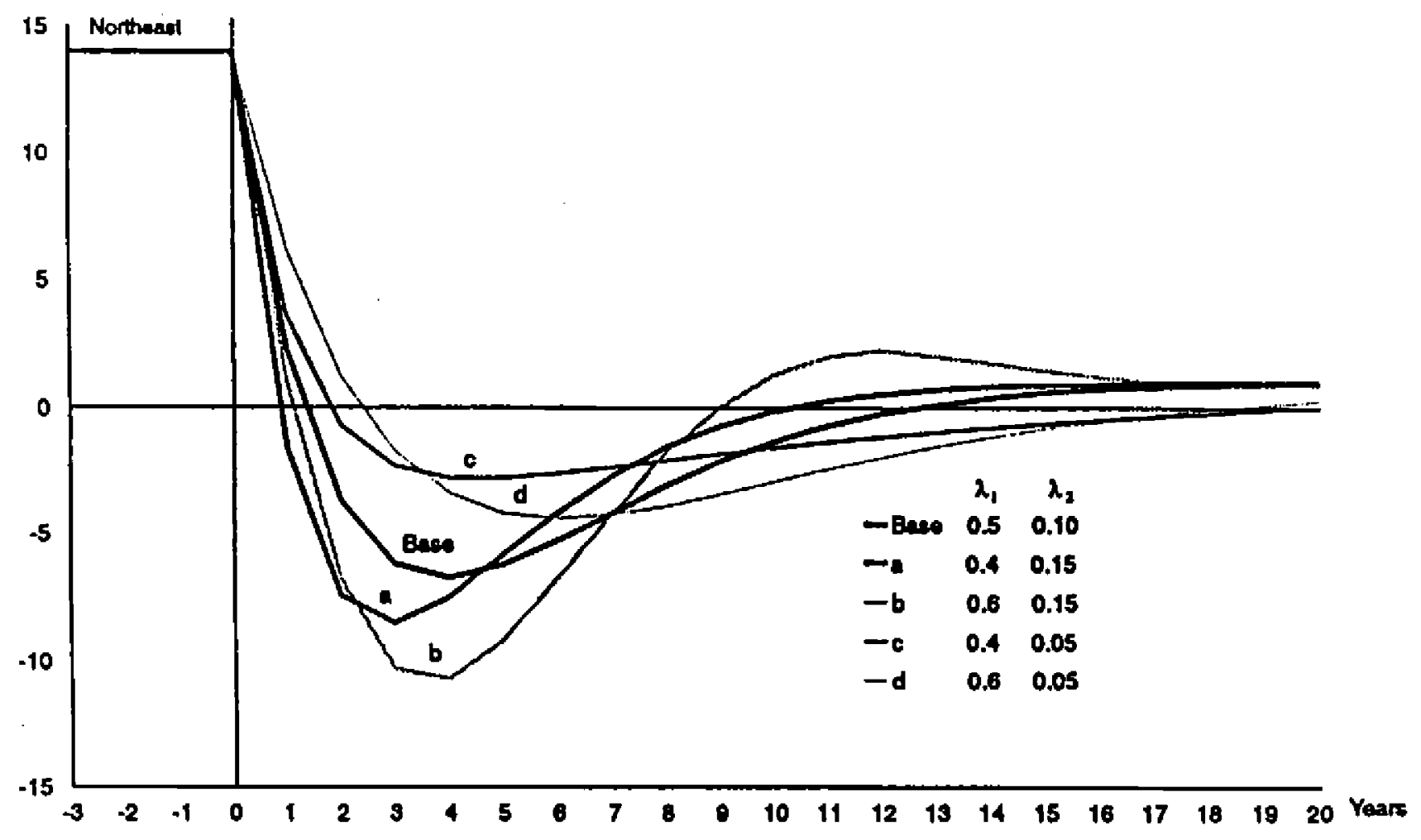


Figure 3

Simulation of House Price Paths

with Alternative Equilibrium Growth Paths

(Percent)

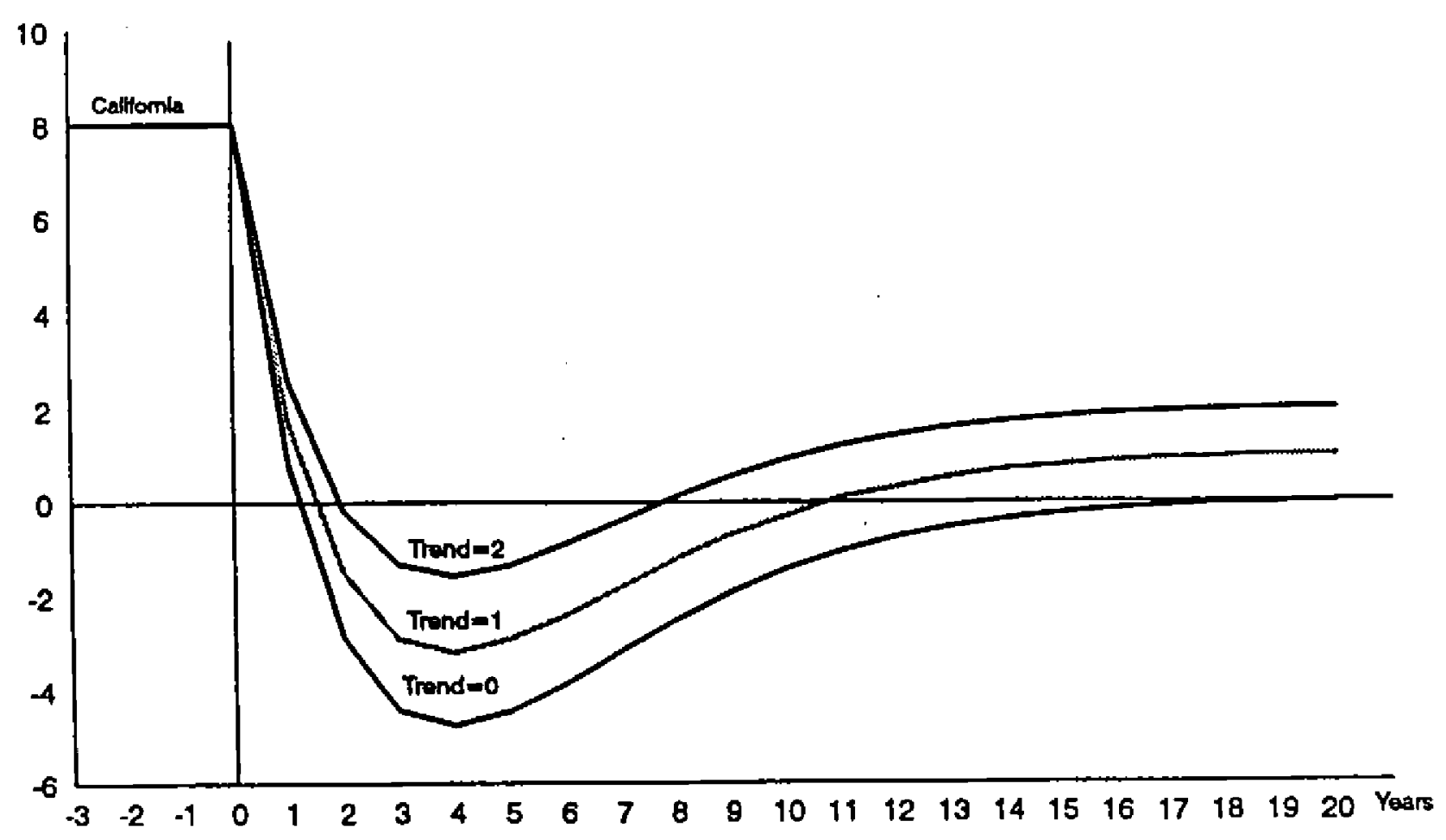

